\title{
Remembering Bernard Juillerat. Visiting the Bánaro after Richard Thurnwald
}

\section{Marion Melk-Koch}

\section{(2) OpenEdition \\ 12 Journals}

\section{Electronic version}

URL: http://journals.openedition.org/jso/6075

DOI: $10.4000 /$ jso.6075

ISSN: $1760-7256$

\section{Publisher}

Société des océanistes

\section{Printed version}

Date of publication: 15 December 2010

Number of pages: $29-40$

ISBN: 978-2-85430-027-7

ISSN: 0300-953x

\section{Electronic reference}

Marion Melk-Koch, «Remembering Bernard Juillerat. Visiting the Bánaro after Richard Thurnwald », Journal de la Société des Océanistes [Online], 130-131 | 2010, Online since 15 December 2013, connection on 09 June 2020. URL : http://journals.openedition.org/jso/6075 ; DOI : https://doi.org/ $10.4000 /$ jso. 6075 


\title{
Remembering Bernard Juillerat. Visiting the Bánaro after Richard Thurnwald
}

by

\author{
Marion MELK-KOCH*
}

\begin{abstract}
Bernard Juillerat followed in Richard Thurnwald's footsteps as a result of their common interest in the impact of specific social structures on the psyche of individuals. Both considered research in New Guinea as particularly rewarding for answering such questions in an area unaffected by European-American culture. This article will discuss Bernard's restudy of a group of people, living by the Keram river, which had first been contacted by Thurnwald in 1913 and had been described by him as "the Bánaro". Their complex social structure, analysed by Thurnwald in two different publications in 1916 and 1920, made them the subject of one of the earliest monographs on a Melanesian society. In restudying and analysing Thurnwald's work Juillerat, like Thurnwald, contributed significantly to the history of ethnology.
\end{abstract}

Keywords: Papua New Guinea, Sepik, Bánaro, kinship systems, intellectual history, restudies

Actually, I did not really know Bernard Juillerat. In addition, my French was and is not good enough to comprehend fully his profound explanations of philosophical and psychoanalytical questions. My memories of him are letters, Christmas cards and two personal meetings one in Berlin shortly after the fall of the Berlin Wall in the summer of 1991 and another one in Paris where Marie-Claire Bataille-Benguigui had invited us for dinner and where it turned out, during a conversation, that we knew each other.

\section{RÉSUMÉ}

Bernard Juillerat, en s'intéressant aux effets des structures sociales sur la psyché individuelle, a mis ses pas dans ceux de Richard Thurnwald (1869-1954). Tous deux sont allés en Nouvelle-Guinée enquêter spécialement sur ce sujet et tâcher de l'élucider en s'affranchissant des influences culturelles européennes ou américaines. Le présent article discute l'étude à nouveaux frais qu'a donnée Bernard d'un groupe vivant sur les rives de la Keram, auparavant contacté en 1913 par Richard Thurnwald qui l'a décrit sous le nom de "Bánaro», et qui lui a consacré une monographie dont il a livré deux versions. Ces deux savants ont apporté de la sorte une contribution marquante à l'histoire de l'ethnologie.

Mots-CLÉs : Nouvelle-Guinée, Sépik, Bánaro, systèmes de parenté, histoire intellectuelle, études critiques

Bernard Juillerat, who was living on the same housing estate, agreed spontaneously to forsake a very interesting TV discussion about the situation in Afghanistan, which had absorbed his attention, and to keep us company. It was a very agreeable evening.

Our point of contact was Richard Thurnwald (1869-1954) and his two monographs about the Bánaro. (i) 1916 Bánaro Society. Social Organization and Kinship System of a Tribe in the Interior of New Guinea, in Memoirs of the American 
Oc53.

Me12.

\section{DER GEMEINDE DER BÁNARO}

Ehe, Verwandtschaft und Gesellschaftsbau eines Stammes im Innern von Nen-Guinea

Aus den Frgebnissen einer Forschungsreise 1913-15

Ein Beitrag zur Entstehungsgeschichte von Familie und Staat

von

Dr. Richard Thurnwald,

Privatdozent târ Ethnologie und Völkerpsychologie an der Universităt Halle a.s.

Mit Stammbäumen, Plänen und Diagrammen etc.
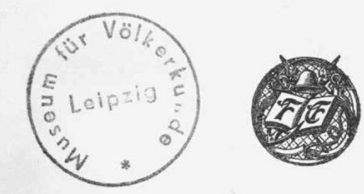

$2: 11173 / 1964: 1532$

ST UT T G A R

VERLAG VON FERDINAND ENKE

1921

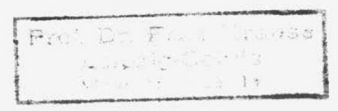

Document 1. - Title page of the 1921 Bánaro monograph in German

Anthropological Association, Vol. III, No. 4, Lancaster, Pennsylvania, and (ii) 1921 Die Gemeinde der Bánaro. Ehe, Verwandtschaft und Gesellschaftsbau eines Stammes im Innern von Neu-Guinea. Aus den Ergebnissen einer Forschungsreise 1913-15. Ein Beitrag zur Entstehungsgeschichte von Familie und Staat. Stuttgart ${ }^{1}$.

In October 1988, I received a message from the Berlin Museum of Ethnology telling me that a French colleague had made inquiries about unpublished materials on Richard Thurnwald's research during the latter's stay with the Bánaro and would like to get in contact with me. From the Berlin Museum he had learned about my work on a doctoral thesis about the two big expeditions of Richard Thurnwald to the former German South Seas Protectorate and he himself planned a «restudy» of this population group. In 1911, the German Government - the «Reichs-
Kolonialamt» - and the Royal Museum of Ethnology in Berlin had organised an interdisciplinary expedition to explore the inner part of Kaiser-Wilhelms-Land along the Sepik river. This primarily geographic exploration included anthropological and ethnographical research as well. The group, consisting mainly of Roesike, Behrmann and Thurnwald - who joined a year later - found several tributaries of the Sepik. In 1913, Richard Thurnwald and the geographer Walter Behrmann, were both participants on the «Kaiserin-Augusta-Fluss Expedition», as the Sepik was called during the German colonial period. They were the first to contact the Bánaro, who lived on a tributary of this river.

Here it is necessary to somewhat develop my own research. This will help understand the problems Bernard Juillerat had in finding documents relating to Thurnwald's work about the Bánaro. As they are kept in several places throughout the world, the search for Thurnwald's archives reads a little bit like detective work. By autumn 1988, I had nearly completed my thesis. And when Bernard's inquiry reached me, I was about to map some important details concerning Thurnwald's research in New Guinea. It was to become an interesting and unexpected discovery for the field of historical ethnology. And this discovery dealt precisely with Thurnwald's monograph about the Bánaro, which was first published in 1916 in a short version. In 1921, Thurnwald followed it up with a considerably extended German version.

After the outbreak of World War I, Thurnwald spent a total of one year in New Guinea before he could leave for the United States; he was allowed to take with him only a small part of his collections, field-notes and photographs. Documentation dealing with Richard Thurnwald's collections in the National Archives of Australia in Canberra, shows that none other than Winston Churchill himself decided on the fate of these items, which today are located for the most part in Sydney. Thurnwald's collections comprised ethnographic and geological specimens, sound recordings, photographs, drawings and sketches of maps and field-notes.

Due to the wartime situation it was impossible for Thurnwald to return home by a direct route, so he took the chance to try the way back to Germany via the United States. At the University of California in Berkeley, Thurnwald encountered great hospitality and came into close contact with colleagues of German descent like Alfred L. Kroeber and Robert Lowie, 


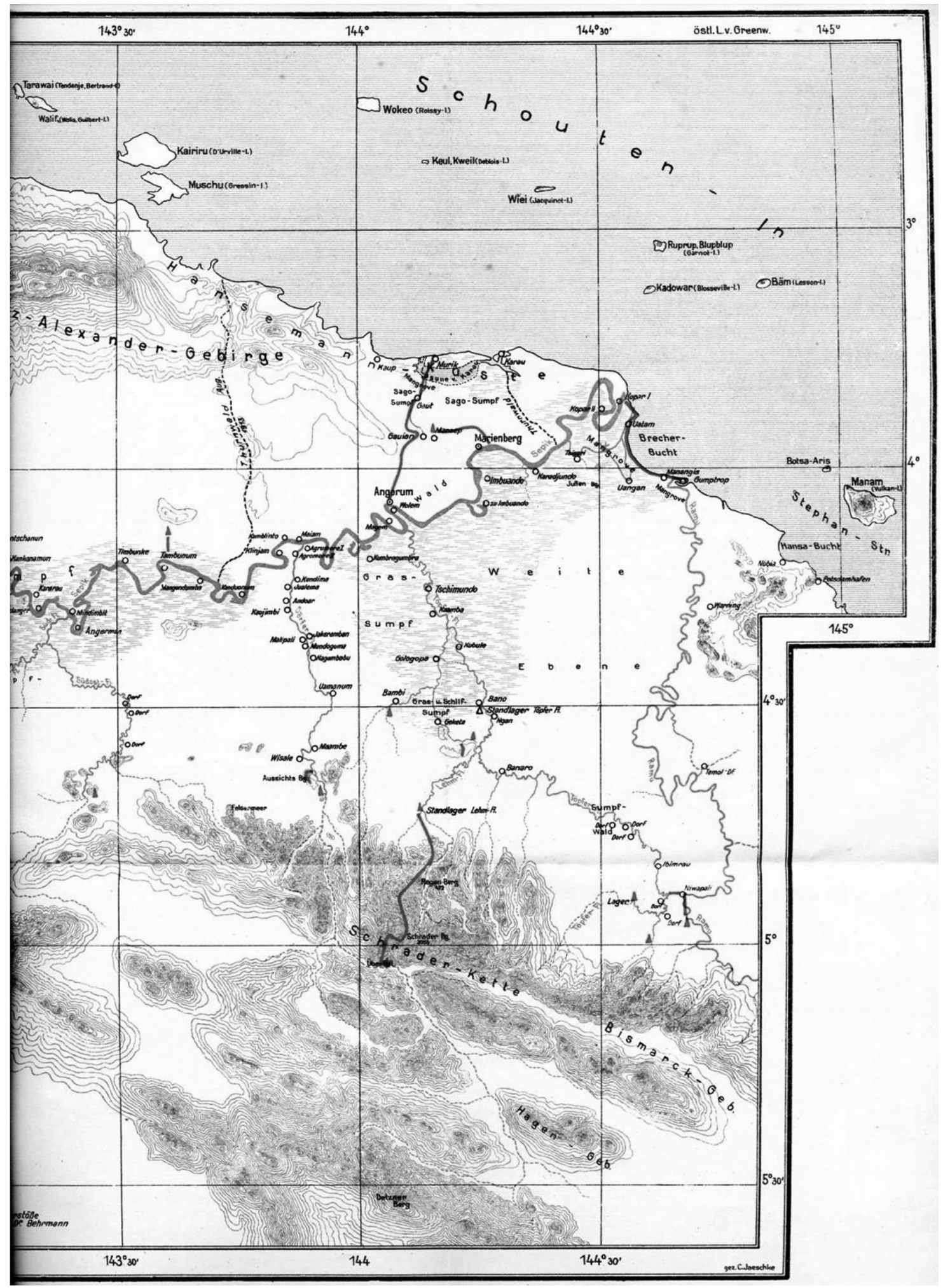

Document 2. - Map taken from Behrmann (1922)

amongst others. There, at that time, the systematic analysis of classificatory kinship systems was an important topic. Thus in 1916, when the first publication about the Bánaro was released, it was a late-breaking publication of his research results. Thurnwald could not complete the proof-reading because he was forced to leave the U.S. precipitately, after the country entered the war. Once again he was not able to take his remaining records with him to Germany. Part of 
the documents remained in Berkeley, another part was lost on the way to New York City when mailed later. Some of Thurnwald's documents are still kept in the University of California, Berkeley, among them some handwritten copies of Thurnwald's texts made by Kroeber. For the German version of the Bánaro publication Thurnwald had even fewer documents at his disposal. Moreover, he had to leave his ethnographic collection behind - as before in Australia. He was not allowed to take pictures and documents with him from the U.S. In San Francisco, he left behind 47 boxes, 3 boxes with photographs and 7 boxes with notes, as well as valuable maps and collections. (For details see MelkKoch, 1989: 249, 2000: 53, 68; Graig, 1997: 387, 404.)

It was not easy to reconstruct these processes to this point. Additionally, I heard about the documents in Berkeley and the other documents concerning the collection in Sydney only when I had already completed my doctoral thesis. Yet I had found essential indications, e.g. in the archives of Yale University where at least part of Thurnwald's scholarly archives from the thirties are kept. In fact, complete archives of Thurnwald's work do not exist. However, since in 1931 Thurnwald had obviously taken with him a part of his left-over documents for his lectures to Yale and because these documents contained passages relating to his research, it was possible to complete the puzzle with the help of tiny indicators. Probably due to the politically and materially uncertain situation in Germany at the time, Thurnwald left his documents - even important private ones - in the house of a colleague in Yale. Thanks to this windfall, today we are at least able to read up on his teaching activity and his contacts with American research colleagues in the nineteen thirties and furthermore gain a view of his research periods in the South Seas.

But let us go back to square one: The starting point for my thesis were two preserved collections of letters of Thurnwald's research in the years 1906-09 and 1913-15 and the beginning of a travelogue from 1906 to 1907 . But soon it turned out that for the examination of the background - and thus for the understanding of his publications - it was necessary to do more than limit myself to the period of pure field research. Consequently, my thesis became more and more about the exploration of his early years - and hence of the scientific background -, of a man who became later such an influential social scientist. From reading the «Letter Diaries» (this is the working title) for the first time as well as combing through the correspon- dence files that were preserved in the Berlin Ethnological Museum, more questions than answers arose. First and foremost, the numerous publications and results of Thurnwald's first travel heavily contradicted the letters between Thurnwald and his supervisor Felix von Luschan, head of the department of Oceania in Berlin. Many of the connections remained completely in the dark and could not be enlightened even by the articles distributed in multitudinous journals and anthologies (many of them were fortunately available as offprints in the Ethnological Institute of the Berlin Free University, which was founded by Thurnwald after World War II). It was necessary to discover new sources! Where, for instance, were Thurnwald's fieldnotes from New Guinea and the manuscript of the second volume of his Buin monograph which was never printed? Where were the linguistic field-notes and the maps drawn by him? What was his life like before the journeys and after his return in the middle of World War I? What happened to his scholarly archives - if they existed at all? Where were the photographs and the phonograph wax cylinders with his phonographic records? It was only after the fall of the Berlin Wall that it was possible to answer the last question, what was that probably the major part of his photographs was located in the basement of the Ethnological Institute. Some of them could be incorporated in the publication of my thesis in 1989.

Of course, beyond the purely biographic and «material» questions, it was necessary to take into account several scientific questions and approaches. How did his contemporaries evaluate his work, what is its reception today (or rather how was it in 1989)? And, a topic for which there was unfortunately not enough space and time: what is life like today in the regions, which he visited? What do the people there think about the statements concerning their culture? Bernard Juillerat's great merit is that he attended in detail to the last question for the Bánaro. And without him, both of Thurnwald's publications about the Bánaro would possibly still be buried beneath the dust of history. From October 1989 to the spring of 1990 , he spent four months with the group which Thurnwald had called the Bánaro.

What were the relations between Thurnwald and Bernard Juillerat? First and foremost, it was probably their common interest in psychological research. Thurnwald's objective of his stay in the South Seas consisted not only in collecting items for the Ethnology Museum in 
Berlin but also in gaining knowledge about the thoughts and feelings of the indigenous population. Maybe this was even the main driving force for his journeys. From early on, Richard Thurnwald occupied himself with this new discipline, as it then was, studied the works of experimental psychologists and tried to combine sociology, psychology, economics and «peoples' science», which is how he described it himself. Thus, psychological explorations were already one of his main topics during his first field research in Oceania. In 1906, after long preparations, he travelled to the German South Seas Protectorate, German New Guinea, with a comprehensive catalogue. This had been put together in collaboration with different professional representatives, extended by himself and entitled Ethnographische Fragesammlung zur Erforschung des sozialen Lebens der Völker außerhalb des europa-amerikanischen Kulturkreises (Collection of Ethnographic Questions for the Exploration of the Social Life of the Peoples Outside the European-American Cultural Area). Between 1908 and 1909, Thurnwald spent several months in southern Bougainville, in Buin. More details about his journeys and his background as well as about the research results, can be found in my 1989 thesis.

Back from his first journey, which lasted from 1906 to 1909 , he managed to publish two volumes on Buin, based on localised fieldwork which had taken at least a few months. Lieder und Sagen aus Buin (Songs and Legends from Buin), the first volume of his Forschungen auf den Salomo-Inseln [...] (Research on the Solomon Islands...), published in 1912, is a comprehensive example of his attempt to learn about the human mind and its perception. In 538 pages, he published (in inter-linear transcription) and analysed 139 song texts. With his «rendering of Stone Age Literature», as he himself calls it, Thurnwald became a poet himself and pursued his goal of keeping as the basis of his work things he really had heard and seen and letting the indigenous people themselves interpret their culture ${ }^{2}$.

So Bernard Juillerat and Richard Thurnwald similarly turned mental processes into a focus of their research. Thurnwald's correspondence from his first journey with Professor Karl Stumpf, the founder of the Phonogram Archive in Berlin, and Erich Moritz von Hornbostel demonstrates that he had a keen interest in this topic. He knew very well that he could not manage this when just passing through: "You cannot think of research trials while you are on the road. For this, you need a longer stay at a particular location and some contact with the indigenous people» (22.3.1907, Files of the Phonogram Archive, Staatliche Museen Berlin Preußischer Kulturbesitz). Confronted with these letters, suddenly, some of the field-notes make unexpected sense. There are also sound recordings of the Bánaro, which are preserved in the Sound Archives of the Berlin Museum of Ethnology (Ziegler, 2006:290-291).

To me, Thurnwald's monograph on the Bánaro by the Keram River in New Guinea seemed incredibly boring at first. Browsing through the two different versions in search of some information, which I could use to reconstruct his two journeys into the now long-gone world of German New Guinea, these books did not produce any useful results at all - this is hardly surprising, but I understood this only later, after sifting through all his publications and remaining parts of correspondence that had also survived, trying to find more reliable data. Towards the end of my thesis, it became clear why there was such a mystery around his monograph(s) on the Bánaro. To cut it short: Aside from the fact that Richard Thurnwald spent nearly seven years «in the field», his «monographs» on the Bánaro are the only ones he ever wrote on a Melanesian society - but... he never really stayed with these people.

While in 1913 Thurnwald regretted that he did not have enough time for conducting research on the Keram river, which they had named Töpferfluß, he was to get another chance to learn more about the life of the people there. Right from his first stay, he was interested in the social structure of the Bánaro. Then, two years later, he could get detailed information about them. In 1915, unable to return home and waiting in Marienberg, one of the British occupation officers provided him with two «boys», Jomba und Manape, who hailed from this region, and Thurnwald was able to work with these two informants for five months. When returning the two boys to their home village, however, he failed in his desire to get into direct contact with the indigenous people. Unlike the other villages, he was not allowed to enter the village of the Bánaro, the «50 Kilometers Village» because the inhabitants were hostile towards him. So he had to rely on what these two, obviously not fully initiated, young men told him.

2. Gerald Camden Wheeler's 1926 Monu-Alu Folklore, dealing with song and narratives of the Shortland Islanders as well as coastal Bougainville peoples is in many respect a counterpart to Thurnwald's Lieder und Sagen aus Buin. Thurnwald and Wheeler did fieldwork at roughly the same time in Buin and Mono-Alu and met at least once. 


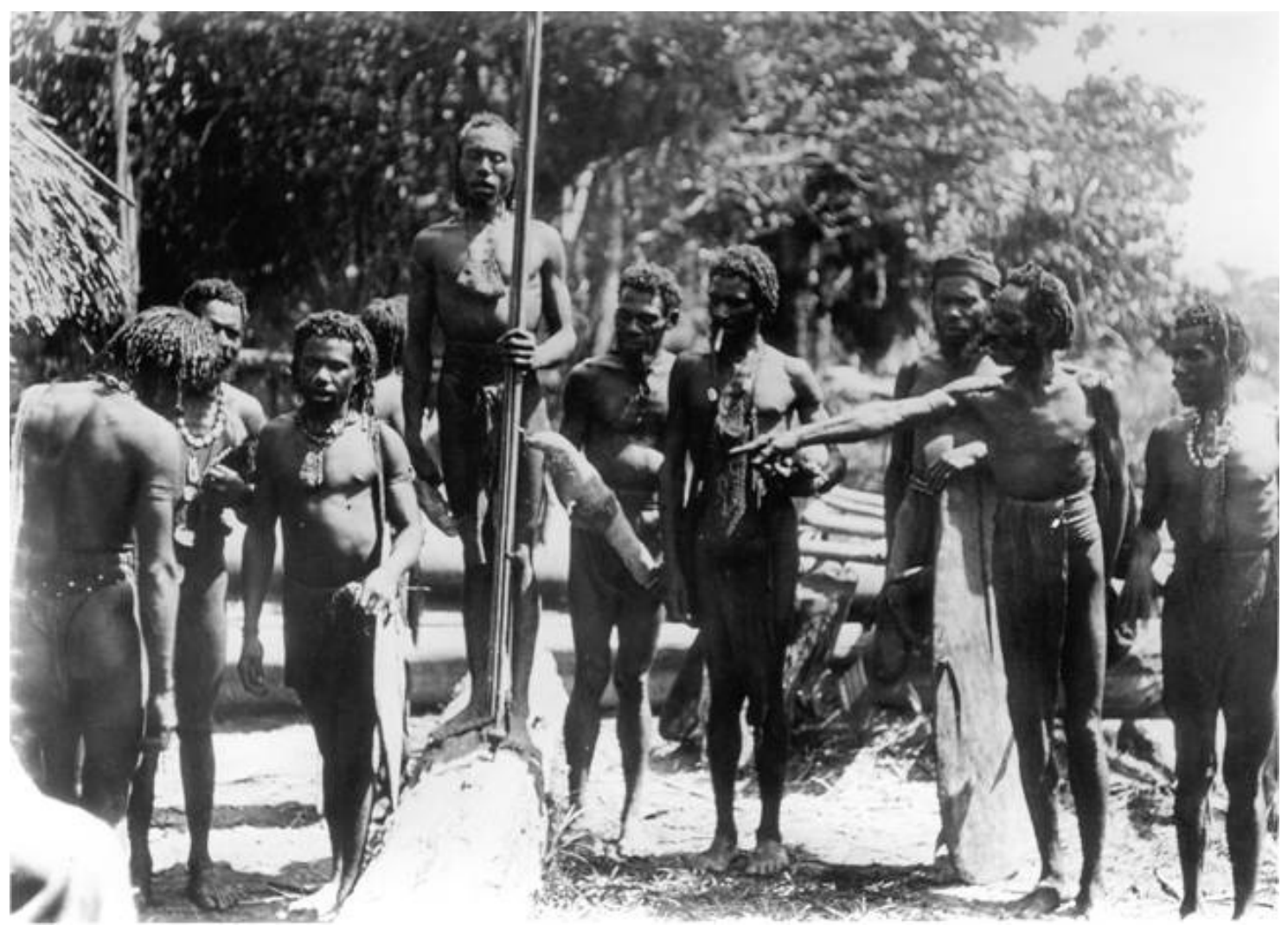

Document 3. - Men in the «50 km village», Angisi, June 1, 1913 (photograph by Richard Thurnwald)

Thurnwald wrote his monograph(s) on conjugal relations at a time when he himself had a lot of problems with the perception of the institution of marriage. Thus, being aware of his personal situation, it is in retrospect not surprising that the volume, dealing with the representation of processes which were described by his informants, goes far beyond a philosophic reflection on these processes.

Thurnwald was among the first ethnographers to define the terms he used. Sometimes he did this to such an extent that, in the first pages of the 1921 publication on the Bánaro, there were only three lines of text but three and a half pages were filled with footnotes. He quoted the most recent publications by Rivers, Vierkandt, Foulkes and others to make sure that the reader could easily and precisely understand the concepts he was talking about when using the terms «clan, kin, family, tribe, nation». This makes it easier today to follow his arguments. Only a few years later, we owe the separation of ethno-sociological terms from biological ones to Thurnwald (in «Zur Kritik der Gesellschaftsbiologie», 1924 [Criticizing Social Biology]). Sifting and filtering literature, always reconciling and processing the impressions of his own experience, Thurnwald created a basis followed by genera- tions of researchers. One thing seems worth mentioning: he was always looking for examples in European history when it came to specific structures, which seemed exotic to his contemporaries, like the reception of the goblin child (Thurnwald, 1921: 263-264). He was among the first to emphasize the principle of reciprocity in the field of ethnology. (For further discussion see Melk-Koch, 1989: 239-240 and Tuzin, 1994: 516517.)

It is this monograph on the Bánaro - especially the more comprehensive German version, which he worked on in parallel with his state doctoral thesis on the Psychologie des Primitiven Menschen (1922, Psychology of the Primitive Mind). Thurnwald used the word primitive not in a sense of being inferior, but in the sense of earlier or prior, but sometimes it is very confusing. Both analyses were based on his search for the basic structure from which modern human society emerged. His monograph on the Bánaro where his own filtering process of extensive literature combined with his experiences in the field made him leave behind every evolutionistic approach. Donald Tuzin in his review of Bernard's book La révocation des Tambaran calls him «a maverick in early twentieth century social science..., whose breadth of vision was ill-fitted 
to the prevailing intellectual schools. Surveying the ruins of classical evolutionism from the perspective of comparative law, Thurnwald asked how the state did, indeed, evolve - as it must have done - out of elemental exchange and authority arrangements; hence his interest in contemporary primitive societies... Thurnwald's broad synthesis was rationalised by a functionalism quite advanced for its time.» (Tuzin, 1994: 517).

Today, in biographic volumes or texts on the history of German ethnology, Thurnwald often is regarded as an evolutionist. But from the very first beginning, he was far away from that. His analytical work on the Bánaro, the «sifting» of all related literature which was accessible to him, taking into account his own experience, the discussions with experts at first in Berkeley and later in Germany had an essential impact on his future scientific oeuvre. In Thurnwald's work the Bánaro publications mark the transition from a classification of human social systems related to the history of the development of mankind to his almost systemic theoretical approach in the thirties. The process of social «sifting», which Thurnwald increasingly pursued in the twenties, was phrased by him («Siebungstheorie») and went down as an important theory in the scientific history of ethnology and sociology. To this very day it has far-ranging effects for the social sciences (Melk-Koch, 1996:71-81).

As already mentioned, I was seeing the Bánaro work as totally theoretical and «dry», not to say «fleshless», as the descriptions were so far removed from what I had expected to learn about daily life in a special village. Thus I was quite surprised when Bernard Juillerat's letter arrived, asking about Thurnwald's stay with the Bánaro. Furthermore, he told me that he intended to go there to figure out the changes that had taken place since 1915 . This was the very beginning of my career in the field of Oceania and I had no idea at all about who this person was who had an interest in this dusty and dry description of mainly «Heiratsregeln» (marriage rules), hardly ever mentioning the real life of the people! But the Bánaro were amongst the earliest group in today's Papua New Guinea, whose social structure was described in a monograph. And it took another 74 years until another ethnologist dealt with the local social structure and its change.

My letter to Paris in autumn 1988, in which I indicated that actual scholarly archives of Thurnwald did not exist, was followed by a deepening correspondence. Initially Bernard Juillerat's research was, as he wrote to me (on July 16th, 1989), relatively open:

«At first, I want to make clear that I am interested in Thurnwald because I would like to understand the present culture and the social system of the Bánaro and thus learn how both of them have been transformed in the last 75 years. The problem of transformation is interesting to me, however, not so much from a descriptive (social and economic) but from a cultural point of view.»

Unlike many of his colleagues, he was also able to read German-language literature. During his own research on the Sepik, he must have encountered Thurnwald's «Die Gemeinde der Bánaro», which he took as a basis for his «restudy» in 1989/90. Unfortunately, a proposed meeting between us in Paris in early October 1989 did not take place. My book about Richard Thurnwald was published only after his departure and he came across a copy of it by chance at the Institute of P.N.G. Studies and was able to read it immediately. Afterwards, he wrote a review of it, which was published in L'Homme in 1991.

Right after his return in January 1990, Bernard summarized the results of his field research in a letter to me as follows:

«So I returned from the Bánaro Community. In this short letter I can only say that many (nearly all!) things, which Thurnwald described, are lost. Today's Bánaro are deeply christianized and have forgotten everything to do with the cult of 'Haus tambaran'. The changes started during World War II when a catholic missionary stole all the woodcarvings from the 'Haus tambaran'. It was also difficult to get a confirmation of the 'mundu institution'; it was only in Bagaram that I saw a man who was a 'goblin child' himself. The 'mundu' system is also lost. What I read in 'Thurnwald's Diary'[...] and in your book makes me understand that Thurnwald had conducted field research for only five weeks next to Yar in 1913 and moreover had worked with these two boys (whose names the Bánaro remember to this very day: they were kidnapped by the Germans two years before) in Madang and Marienberg. In fact, Thurnwald's material about the people whom he called the 'Bánaro' (Central Bánaro: Kivim, Angisi, etc.) is related to the Bánaro in the Bagaram and Yar villages, which he did not regard as 'Bánaro'[...].» [Revised translation from the German text, dots by Bernard, January $13^{\text {th }}, 1990$ ]

Bernard combined this letter with the request for other information and details, which I was able to send him time and again over a period of two years. He always appreciated this in his letters and thanked me several times for our good collaboration and my assistance. Thus, the results of my research, copies of the photographs 


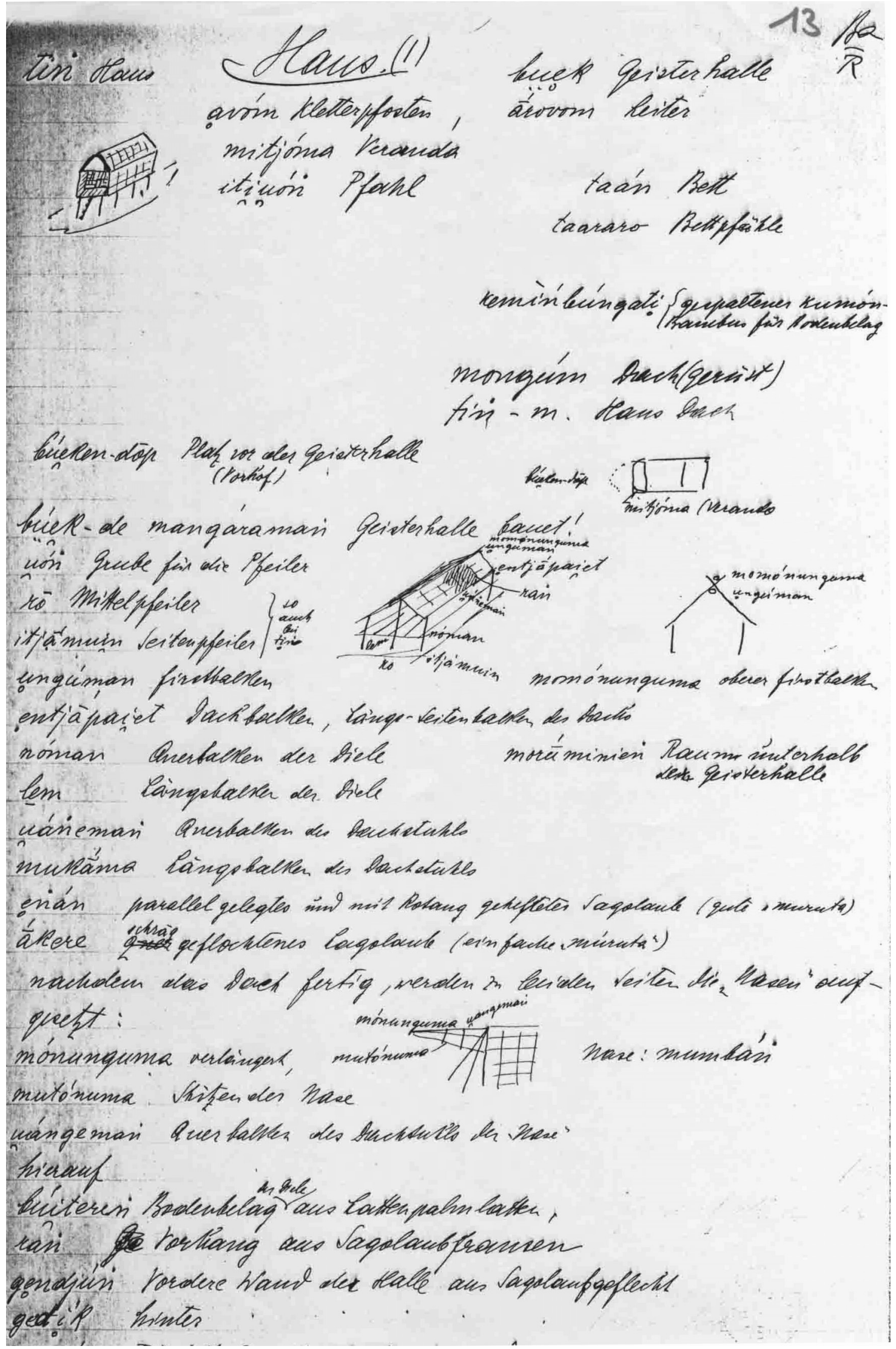

Document 4. - Field-note by Richard Thurnwald from 1915, describing the Haus tambaran. (Australian National University, Department of Linguistics) 


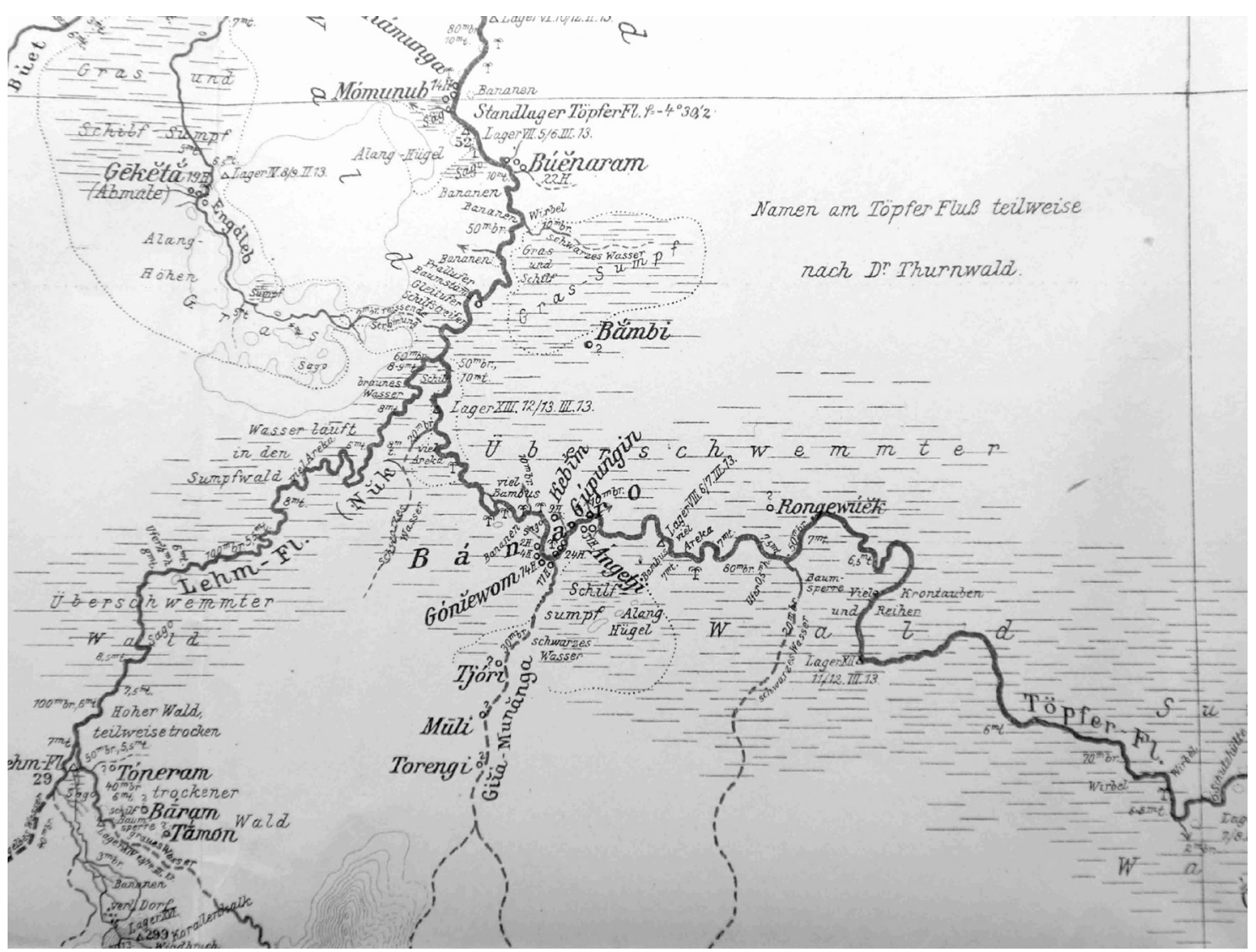

Document 5. - Settlement area of the Bánaro according to Thurnwald's and Behrmann's research 1913/1915 (Detail from Walter Behrmann 1924 map 3)

recovered by me, copied articles, which were not available in the libraries in Paris (and not only there), and even my original copies of Thurnwald's correspondence from the archives in Canberra and Yale went from Berlin to Paris.

To my surprise and during the actual revision of our correspondence when writing this article, I noticed the following sentence by me at the end of a long section of information:

«I hope that I have informed you exhaustively. However, I would like to ask, why are you so sure that the "Bánaro system" really corresponded to Thurnwald's description? Awaiting your research results with anticipation [...]» (January $\left.31^{\text {st }}, 1990\right)$.

Bernard gave me a detailed reply, starting with the different place names and the changes that had occurred in the villages during the last decades but mainly after the Japanese occupation of this area in WW II. His analyses were published, as already mentioned, in the 1993 monograph $L a$ révocation des Tambaran. Les Bánaro et Richard Thurnwald revisités, and in an article in Gradhiva that same year. In 2000, he published a paper in Oceania, using the most crucial question as its title: «Do the Bánaro Really Exist? Going Back
After Richard Thurnwald». Indeed, I found this article coincidentally and if he had sent me this text for a comment, it was probably lost in the mail due to our moving to Leipzig in 1997. Our intensive correspondence in the early nineties was followed by some Christmas cards. Afterwards, we lost sight of each other until that evening at Marie-Claire Bataille-Benguigui's.

Thus, two decades ago, Bernard Juillerat started a journey to a group of descendants living on the Keram River for a «restudy» - well prepared thanks to his own field experience and Thurnwald's publications. With regards to content, I think that up to now with the publication of Bernard's article: «Do the Bánaro Really Exist? [...]», Donald Tuzin's review in Man 1994, and Robert Parkin's 1993 review of La révocation des Tambaran: les Bánaro et Richard Thurnwald revisités in Sociologus, there is really not much to be added to Bernard Juillerat's information about the Bánaro, Richard Thurnwald and all the various related questions for our discipline. Parkin also gets to the heart of the matter that Thurnwald, who in Germany is not really regarded as being a theoretician can now be seen just as such thanks to the work of Bernard Juillerat. 
Concerning the numerous corrections of Thurnwald's descriptions of the Bánaro social life made by Bernard, he remarks:

«he consistently writes sympathetically about Thurnwald himself and about his unique distillation of the ideas of his time and the more original insights that he drew from them. Thurnwald's status as one of the most significant figures of pre- and post-war nonMarxist, liberal German ethnology will not be diminished [...].» (1993: 96)

The more I immersed myself into the review of all my documents and the correspondence between myself and Bernard Juillerat for this article, the more I understood that with regard to content, I cannot add anything new because I had provided all the details of my research for Bernard Juillerat's study. This «restudy» of the Bánaro is also a good example of scientific collaboration, which was always taken for granted by Thurnwald. Is there a better compliment for an author than to see his/her own work as a sensible basis for future research? Certainly, there are utterances of Thurnwald which I interpret in a different way from Bernard Juillerat, but possibly in ten years there will be another evaluation and classification of his theories and works. Thus, the only (but very important) point for correction because I am quoted as a witness in this matter is Bernard's statement that Thurnwald took allegedly no stock in stationary field research (2000: 34). The exact opposite is the case, I have demonstrated this several times in my doctoral thesis. He already wrote as soon as 1912 in his Buin publication, in which his particular concern was to let people speak for themselves:

«For an exact ethnology, we need to bring documents to life and thought; we do not need the opinions of others about indigenous people but their own opinions.» (1912: 2)

Of course, this is only possible after a long stay on site and this is also implied in the remark already quoted in which he deems a longer stay at a particular location important for an authoritative study of a people. Concerning the Bánaro themselves, he posed the question of how the «Bánaro system impacts upon the character of men and women. In order to answer this question exhaustively, you need to stay for several years and deal with the indigenous people in detail» (1921: 257). While restudying the sources, I was shocked by Thurnwald's incredibly hard personal living conditions at the time when he was composing the second, extended Bánaro publication: hunger, cold, transporta- tion difficulties, lack of professional perspectives in spite of an enormous personal commitment, lack of hope of one day marrying the woman he loved. Hilde, who was eventually to become his wife and companion - and an anthropologist (1934, 1937).

Finally, after twenty years I was once more made aware of the fact that Thurnwald's Bánaro writings, which at a first glance had been so boring for me, go far beyond a monograph on people in Melanesia. Whatever the real social structure of the Bánaro was - even the question about the correctness of the information of Thurnwald's informants on initiation and sexual behaviour -, it is no longer possible to ascertain, in spite of Bernard Juillerat's «restudy». Whether these Bánaro existed as a «tribe» in this form or not - it does not really affect the importance of this publication. What remains is a work that marks a transition of our discipline out of the «biological» paradigm towards a social science. Obviously, Bernard Juillerat discovered this as well. Thurnwald's Bánaro society is an epoch-making work, whose theoretical importance is independent from the real life of the people he called the Bánaro. Thanks to Bernard, this insight was brought out of retirement on dusty book shelves. His question: «Do the Bánaro really exist?» hits the crucial point. However the answer is that after three quarters of a century, Bernard Juillerat gave the people, described as the Bánaro, a chance to comment on what was written about their ancestors.

\section{BIBLIOGRAPHY}

Behrmann Walter, 1922. Im Stromgebiet des Sepik, Berlin, August Scherl.

-, 1924. Das westliche Kaiser-Wilhelms-Land in Neu-Guinea, Zeitschrift der Gesellschaft für Erdkunde zu Berlin, Berlin.

Craig Barry, 1997. The fate of Thurnwald's Sepik ethnographic collections, Gestern und Heute - Traditionen in der Südsee, Berlin, Dietrich Reimer, Festschrift zum 75. Geburtstag von Gerd Koch, pp. 387-408.

JuILleRAT Bernard, 1993. La révocation des Tambaran. Les Bánaro et Richard Thurnwald revisités, Paris, CNRs Éditions.

—, 1993. Richard Thurnwald et la Mélanésie : réciprocités, hiérarchies, évolution, Gradhiva 14, pp. 15-40.

—, 1991. Compte rendu de M. Melk-Koch, Auf der Suche nach der menschlischen Gesellschaft: Richard Thurnwald, L'Homme 31, 120, pp. 115-118. 
—, 2000. Do the Banaro really exist? Going back after Richard Thurwald, Oceania 71, pp. 46-66.

Melk-Koch Marion, 1989. Auf der Suche nach der menschlichen Gesellschaft: Richard Thurnwald, Berlin, Dietrich Reimer Verlag, Veröffentlichungen des Museums für Völkerkunde Berlin. Neue Folge 46.

_, 1991. Thurnwald Richard (Christian), in Walther Killy (Ed.), Literaturlexikon 11, Munich, Bertelsmann Lexicon Verlag, Autoren und Werke deutscher Sprache, pp. 356-365.

_, 1992. Don Laycock - Corrector Antiquorum, in Tom Dutton, Malcolm Ross and Darrell Tryon (eds), The Language Game. Papers in Memory of Donald C. Laycock, Canberra, The Australian National University, Pacific Linguistics Series C 110, pp. 257-262.

—, 1996. Richard Thurnwald und die Siebungstheorie, in Anthropologischer Anzeiger Jg. 54, H 1, pp. 71-81.

_, 2000. Melanesian Art or just Stones and Junk? Richard Thurnwald and the Question of Art in Melanesia, Pacific Arts. The Journal of the Pacific Arts Association 21-22, pp. 53-68.

-, 2001. Richard Thurnwald: «Die menschliche Gesellschaft in ihren ethnosoziologischen Grundlagen», fünf Bände 1931-1935, in Christian F. Feest und Karl-Heinz Kohl (Eds), Hauptwerke der Ethnologie, Stuttgart, Kröner Verlag, pp. 480-484.

PARKIN Robert, 1993. Review of La révocation des Tambaran : les Bánaro et Richard Thurnwald revisités, Sociologus, pp. 92-96.

Thurnwald Hilde, 1934. Woman's status in Buin society, Oceania 5, pp. 142-170.

—, 1937. Menschen der Südsee, Stuttgart, F. Enke.

Thurnwald Richard und S.R. STEInMETz, 1906. Ethnographische Fragesammlung zur Erforschung des sozialen Lebens der Völker außerhalb des europaamerikanischen Kulturkreises, Berlin, $\mathrm{Hg}$. von der Internationalen Vereinigung für vergleichende Rechtswissenschaft und Volkswirtschaftslehre.

THuRnWALD Richard,1912. Forschungen auf den Salomo-Inseln und dem Bismarck-Archipel, Bd. 1: Lieder und Sagen aus Buin, Berlin, Reimer.
—, 1912. Über ethno-psychologische Untersuchungen bei Naturvölkern, Verhandlungen deutscher Naturforscher und Ärzte 2, pp. 476-481.

_, 1912. Probleme der ethno-psychologischen Forschung; Zur Praxis der ethno-psychologischen Ermittlungen besonders durch sprachliche Forschungen, in W. STERN and O. LIPMANN (eds.), Beihefte zur Zeitschrift für angewandte Psychologie, Leipzig, Beiheft 5, pp. 1-27 ; pp. 117-124.

_, 1916. Bánaro Society. Social Organization and Kinship System of a Tribe in the Interior of New Guinea, Memoirs of the American Anthropological Association III, 4, Lancaster, Pennsylvania.

-, 1921. Die Gemeinde der Bánaro. Ehe, Verwandtschaft und Gesellschaftsbau eines Stammes im Innern von Neu-Guinea. Aus den Ergebnissen einer Forschungsreise 1913-15. Ein Beitrag zur Entstehungsgeschichte von Familie und Staat, Stuttgart, Sonderausgabe aus der Zeitschrift für vergleichende Rechtswissenschaft, vol. 38 and vol. 49.

—, 1922. Psychologie des Primitiven Menschen, in G. Kafka (Ed.), Handbuch der vergleichenden Psychologie, vol. 1, Munich, Verlag von Ernst Reinhardt, pp. 147-320.

—, 1924. Zur Kritik der Gesellschaftsbiologie, in Werner Sombart und Max Weber (eds), Archiv für Sozialwissenschaft und Sozialpolitik 52, pp. 462499.

TuzIN Donald, 1994. Review of La révocation des Tambaran: les Bánaro et Richard Thurnwald revisités, Man, pp. 516 - 517.

WheEler Gerald Camden, 1926. Mono Alu Folklore (Bougainville Straits, W. Solomon Islands), London, Routledge and Sons.

ZIEGLER Susanne, 2002. Die Wachszylinder des Berliner Phonogramm-Archivs, Berlin, Veröffentlichungen des Ethnologischen Museums Berlin, N.F. 73, Abteilung Musikethnologie, Medien-Technik und Berliner Phonogramm-Archiv XII,.

Other sources

Phonogram archive of the Ethnological Museum Berlin: PhA SMB PK, Thurnwald.

Correspondence Bernard Juillerat/Marion MelkKoch. 
